UDC 81'255. 4

DOI 10.32999/ksu2663-3426/2019-1-32

\title{
METHODOLOGICAL ASPECTS OF TRANSLATIONAL TEXT ANALYSIS
}

\author{
Navrotska Iryna Mykolaiivna, \\ Candidate of Philological Sciences, Senior Lecturer at the Chair of Conversational English \\ Lesya Ukrainka Eastern European National University \\ rasmusia@ukr.net \\ orcid.org/0000-0002-9787-2280
}

The article represents the discussion of theoretical and methodological aspects and the results of the survey, which was conducted to determine syllabus peculiarities of translational text analysis as a course of limited choice for the third year students of foreign philology department. Despite that, the research being undertaken in this branch of translational methodology is relatively new but rather extensive, there is a lack of consistent approaches to the various models of translational analysis of texts pertaining to different contexts of culture and situation. The methodology presupposed translation brief involving situational factors followed by gradual critical reading model of translational text analysis according to field, tenor, and mode strands of macro- and microtextual meanings. The aim of translational analysis and the procedure depended on text typology according to the register, field of expertise, and verbal or nominal character, factors of coherence and cohesion. With some modifications not undermining the approach, this model was suggested as a universal one and proved to be effective. In fact, the students were provided with the plan and text samples, which were assigned and analyzed together with the lecturer. During the verification stage, the students were invited to fill out the anonymous questionnaire containing a set of evaluative questions and statements. The obtained results demonstrate that the students distinguished the main comprehension difficulties as those connected with terminology and the scholars' contributions, whereas the course was mostly regarded as useful and topical regardless of the fact that the majority of students do not have substantial experience and their idea of professional activities as translators is still vague. The respondents also denoted the aspects of lecture rhetorics to be improved and suggested the text types they would like to add as the most challenging. Interestingly, the students especially liked analyzing parallel newspaper texts.

Key words: translation methodology, field, tenor, mode, evaluative criteria.

\section{МЕТОДОЛОГІЧНІ АСПЕКТИ ПЕРЕКЛАДОЗНАВЧОГО АНАЛІЗУ ТЕКСТУ}

\author{
Навроцька Ірина Миколаївна, \\ кандидат фрілологічних наук, \\ старший викладач кафедри практики англійської мови \\ Східноєвропейський національний університет імені Лесі Українки \\ rasmusia@ukr.net \\ orcid.org/0000-0002-9787-2280
}

\begin{abstract}
У статті розглянуто теоретико-методологічні аспекти та результати дослідження, проведеного з метою визначення особливостей програми перекладознавчого аналізу тексту як обмеженої вибіркової дисципліни для студентів третього курсу фракультету іноземної фрілології. Незважаючи на новітній характер та значну кількість проведених у цій галузі перекладознавчої методології досліджень, немає послідовних підходів щодо визначення єдиної моделі перекладознавчого аналізу текстів у різних культурних та ситуаційних контекстах. Згідно з методологією, спочатку був проведений попередній аналіз тексту з урахуванням ситуаційних фракторів: просторових, часових та спонукальних відмінностей, а також мети спілкування, культурних особливостей, пов'язаних зі знанням, досвідом або сприйнятливістю реципієнтів. На наступному етапі було застосовано послідовну модель критичного читання як безпосередній перекладознавчий аналіз тексту за макро- та мікротекстовими значеннями поля, тону та способу. Найсуттєвішою перевагою цієї моделі аналізу є покрокова процедура, що передбачає відповіді на різні питання, що стосуються тематичного, модального та метатекстового компонентів тексту. Такий підхід дав змогу спростити сприйняття складного теоретичного матеріалу й показати, як саме текстовий аналіз збільшує ефективність перекладацької діяльності та визначає вибір стратегій перекладача. Мета перекладознавчого аналізу залежала від типології тексту, регістру, сфери знань, дієслівного чи іменного характеру, фракторів когерентності та когезії. Під час занять було використано та проаналізовано опорний план аналізу та текстові зразки переважно інформативного характеру. На етапі перевірки студентам було запропоновано заповнити анонімну анкету, що містила набір оцінювальних запитань та тверджень. Отримані результати свідчать про те, що для студентів найбільш складним виявився матеріал, пов'язаний з термінологією та досягненнями вчених. Теоретичний курс був охарактеризований як корисний та актуальний, незважаючи на те, що більшість студентів не мають значного досвіду, а їхні уявлення про майбутню професійну перекладацьку діяльність дещо абстрактні. Респонденти також відзначили особли-
\end{abstract}


вості риторики лекцій, які варто покращити, й запропонували найбільш складні типи текстів, які вони хотіли б додати до програми курсу. Цікаво, що студентам особливо сподобався аналіз паралельних газетних текстів. Проведене опитування спонукало студентів до активного обговорення нового курсу з викладачем, підвищило рівень їхньої зацікавленості та профресійної мотивації.

Ключові слова: методологія перекладу, поле, тон, спосіб, критерії оцінювання.

\section{Introduction}

The purpose of this article is to disclose some theoretical and practical aspects of the recently introduced course of Translational Text Analysis (TTA) which was designed for the third year students of the Faculty of Foreign Philology at Lesya Ukrainka Eastern European National University to consolidate their understanding of text analysis involving the concepts and methods of linguistics, relevant to the fulfillment of specific translation tasks. It is the course of limited choice for training in the field of written translation and presupposes the methodological and practical modules combining translation theory discussions and practical sessions in form of seminars. The introduction of the course was predetermined by the faculty requirements and guidelines for translators' training and specilisation.

The courses of this type with some degree of variations and similarity of teaching components and references in the syllabus were developed worldwide in the last few years at Aston University as "Text Analysis for Translation" (Schäffner, 2011); at Riga Technical University by Tatjana Smirnova and Irina Liokumoviča as "Modern Methods of Text Analysis" (for post-graduate students) (RTU, 2017); at McQuire University (Sydney, Australia), Faculty of Human Sciences, Department of Linguistics as "Discourse and Text Analysis for Translators and Interpreters" by Dr Canzhong Wu (Canzhong, 2017); at School of Humanities and Languages by M. Kim as Text Analysis for Translation (Kim, 2017) to name but a few.

The significant contributions have been made in the development of consistent translation analysis theory and methodology by German and Danish scholars, especially C. Nord, A. Trosborg, R. Arntz, e. a. and also Czech (E. Mastnà, 2010) and Italian scholars (M. Manfredi, 2008), whereas diachronically represented applied aspects and approaches were summarized in J. Munday's "Introducing Translation Studies" (Munday, 2001). The detailed algorithm of macro-textual and micro-textual translational analysis was suggested and discussed in his article by Prof. B.J. Careless (Careless, 2014).

Our course is focused on providing students with sufficient knowledge and skills of text analysis based on consistent European fundamentals of translation studies and models of translation, types of equivalence, translation units, text typologies, pre-translational source text analysis, translation strategies, stages of analysis and ultimate discussion of translation challenges.

Students are expected to operate with basic theoretical notions and show their linguistic competence acquired during previously studied translation disciplines such as Theory and Practice of Translation and Lexical and Grammatical Aspects of Translation. In fact, our course presupposes the involvement of the following specific knowledge (Schäffner, 2011): 1. Basic concepts of translation (syntax, semantics, pragmatics, text linguistics, discourse analysis). 2. The ST analysis as an essential pre-requisite for production of a functionally adequate TT. 3. Linguistic concepts relevant for translation-oriented text analysis. 4. Different types of written communication; their communicative functions, text types and related macro- and microtextual features. 5. Key features of informative, argumentative, and expressive ST and respective TTA.

Students are usually not in favour of keeping them overloaded with theory including definitions, especially when such practical activity as translation is concerned, which was also proved by our survey. Thus, we tried to maintain the golden medium when choosing the key notions and aspects of translation to rely on and to demonstrate how this theoretical material conforms to hands-on learning approach.

It is important to highlight some points which were disclosed during the introductory lectures.

Translation studies as a discipline (the term itself was invented by the Dutch scholar J.S. Holmes) emerged in 1970s and has flourished immensely over the last decades. In The Routledge Encyclopedia of Translation Studies (Baker, 1998) it is defined as " $<\ldots>$ the academic discipline which concerns itself with the study of translation". It is actually an interdiscipline overlapping linguistics, literary studies, cultural studies, philosophy, and language engineering. The fundamentals of modern translational text analysis in Ukrainian translation studies were formulated by V. Koptilov (Koptilov, 1972: 187-189).

The phenomenon of "translation" can be defined from different angles, both general and more specialized, as the process of translating words or text or written or spoken rendering of their meaning. Translation of a text is a "representation" or "reproduction" of an original text ST in another language (House, 2001: 247). 
According to R. Bell, from functional aspect translation is: "The transformation of a text originally in one language into an equivalent text in a different language retaining, as far as is possible, the content of the message and the formal features and functional roles of the original text" (Bell, 1991: xv).

In our lectures and seminars we tried to underline functionality as by far the most decisive benchmark for the quality of any translated text, that the "target product" should by no means look awkward as a translated one and that the professional mastership can be achieved only through scrupulous editing, criticism and constant target and source language improvement and, of course, staying alert to the latest semantic and pragmatic trends in the chosen field of specialization.

Functionality is an inalienable feature of translation as a process. "Translation is the production of a functional target text maintaining a relationship with a given source text that is specified according to the intended or demanding function of the target text (translation skopos)" (Nord, 1991: 28).

Interestingly, M. Allen views textual analysis as a methodology involving understanding language, symbols, and/or pictures present in texts to gain information regarding how people make sense of and communicate life and life experiences, highlights the role of different types of context and suggests relevant tips for a researcher conducting textual analysis (Allen, 2017). It can be inferred from this definition that textual analysis involving textual and extra-textual information is of great importance in different spheres of communication nowadays.

There is a number of translation models and types of equivalence, which can be explicated only with reference to texts of different types and genres. For analytical purposes we selected informative texts from printed and electronic sources which might be interesting and challenging for students.

Given that translational text analysis is a relatively young interdiscipline, there is much room for comparative analysis and synthesis of new methodological paradigms of translational analysis which can be applied to text.

In this connection, from critical perspective, Shmiger T. maintains that no universal "crystalized" method of translational analysis can be distinguished due to multiple approaches based on history and criticism of translation and impossible involvement of all textual parameters from source and target languages (Shmiger, 2003: 199-201). In other words, it is worth mentioning here that the choice of methodology always depends on the overall structure of certain languages, cultural, temporal, and personal deixis as well as the functional character of the source and target texts.

Due to various models of equivalence with the focal point of different textual ranks and lexical and grammatical features (Halliday, 1966: 137); dilemma between formal correspondence and textual equivalence (Catford, 1965); translator's metaphorical choice, cohesion markers and the size of translation units (Newmark, 1988: 66); Chomskian deep and surface structures revised by E. Nida in form of functional classes (events, objects, abstracts, relationals) (Nida, 1964: 64) it was problematic to single out a universal algorithm for practical sessions of translational text analysis. It was necessary to demonstrate first how the hands-on strategies employed at different levels of analysis may vary and influence the translator's immediate choice of lexico-grammatical units.

Basically, we inferred that the most suitable model of analysis should therefore combine as many universal features as possible but shouldn't be theoretically overloaded. The best option was to take M.A.K. Halliday's (Hallidayan) model of text and discourse analysis modified by $\mathrm{C}$. Wallace (Wallace, 2003: 39) and to verify its efficiency during the lectures and seminars (Wallace, 2003; Halliday, 1966; Halliday, 1976).

\section{The procedure of text analysis}

At the preparatory stage we highlighted that the translator should be able to infer the purpose of the target text from the translation situation itself (translator's previous experience or routine) and that every translation task should thus be accompanied by a brief (pre-translational analysis) defining the conditions under which the TT should carry out its particular function. This stage presupposes identifying the characteristic verbal and nonverbal features of the ST - situational factors: the difference in place, time, motive and purpose of the communication, difference with regard to the culture bound knowledge, experience or susceptibility of the respective audiences. In this respect, we followed C. Nord's statement that in the professional environment the translation brief is generated by the client giving as many details as possible about the purpose, explaining the addressees, time, place, occasion and medium of the intended communication and the function the text is intended to have (Nord, 1997: 30).

The analysis of the ST is conducted to clarify the translation assignment, to distinguish the units of translation (the selection is based on the sug- 
gested typology of equivalence), to choose certain macro and micro-textual strategies. The aim was modified depending on the textual type (informative, expressive, operative), genre (fiction, scientific, technical, official), medium (newspaper, textbook, official document) whereas the use of strategies depended on the reading stage of the analysis: field, tenor, and mode.

Our methodological framework of translational text analysis was designed in concordance with the reading process division into three stages suggested by C. Wallace following Hallidayan grammar (Wallace 1992; 2003): pre-reading, while-reading, post-reading stages. The readers should focus on the field of the text (i.e., what is going on, theme), then on its tenor (i.e., interpersonal deixis, pragmatic aspects), and finally at the mode (i.e., text organization, cohesion); these three strands of meaning according help readers to concentrate on the effect of the writer's choice and should be regarded simultaneously in the process of translation.

The students were provided with the plan with which any text, regardless of its function, source language, type or style etc. can be characterized at different levels for the purpose of translational text analysis. The most important advantage of this model of analysis is that it contains step-bystep procedure and includes various questions which the students have to answer and it simplifies the process:

FIELD: What is the text about? How are the participants talked about? Who are the major, minor, invisible participants? How are processes talked about (by verbs)? How specifically are circumstances indicated (by adverbs, prepositional phrases)? How is causation attributed (cause and effect relations also indicated by verbs)?

TENOR: What personal pronouns are selected? How does the writer refer to himself? What mood is selected (declarative, imperative, interrogative)? Does the modality help to express the degree of certainty/authority of the writer? What adjectives, nouns, adverbs express this type of modality?

MODE: What is the text's semantic structure (Is it narrative, expository or descriptive?)? What larger structures (units) does the text have (paragraphs)? What type of information is selected for first position, at clause level and the level of the whole text? How does the text hang together?

Thus, these three strands of meaning can be also referred to as: thematic, deictic and metatextual.

The selection of texts was another necessary requirement, so we compiled a set of texts of dif- ferent genres and styles and some of them were demonstrated and discussed already during the lectures. This approach facilitated the students' preparatory training for further practical text analysis.

However, there were some elements which were added to the above mentioned plan on the verification stage. Namely, in technically oriented texts the doers are not extrapolated and the objects turn out to be the main participants if the text is impersonal and unbiased. For example, this was obvious when the text about a new model of Bentley was analyzed. The modality can also be expressed not only by emotionally coloured epithets, but also by attitudinal verbs and uncommon for the specific genre verbal or nominal phrases, often taken in parentheses, inverted commas etc. Texts may have a complex semantic structure disclosed in combination of narrative, expository or descriptive features (for example, a commercial text or clerical sermon). The students liked the idea of searching hidden meta-textual elements in the texts, cohesive, coherent and individualistic features.

\section{Results}

The Choice of criteria and the survey. To tailor the course layout and to modify its syllabus we made a short survey for the students, who have attended the lectures and already actively participated in the seminars, allowing to provide us with the feedback and evaluate educational efficiency of the implemented teaching techniques and identify which positions need revision or adjustment. The list of questions was based on the students' comprehension and individual aptitudes and attitudes regarding the translation skills, strategies, and experience and therefore included the following points:

Questions relating to the lectures: 1. How can you value the usefulness of the course for your future profession as a translator? 2. Were the lectures interesting? Why? 2. How topical (up-to-date) was the material presented in the lectures? 3. Did you attend all the lectures? 4. To what extent do you think the course is difficult, compared to other courses you have taken? 5 . Was the material presented during the lectures comprehensive? 6 . Were there any points which needed additional commentary, clarification etc.? 7. How good were the lecturer's presentation skills? 8. Were the lectures interactive? 9. Would you recommend this course to other students?

Questions related to the seminars: 1. Do you find the planning of the seminars logical? 2. Did you receive enough support materials (lecture drafts, presentations, literature, 
hand-outs). 3. Would you like to add and discuss more/less questions during the seminars (lectures)? 4. How meaningful were the tasks suggested by the lecturer? 5. Did you attend all the seminars? 6. Specify the type of texts which you basically find the most difficult for the professional to analyze and to translate. Why? 7. What texts would you like to add for the analysis purposes? 8. Did you get enough class and extra-curricular consultation opportunities? 9. Is there any likelihood you will use some of the taught skills in your translation practice? 10. Have you ever translated texts as a paid assignment from the client?

Another set of questions was suggested to evaluate quality of lecture material and lecturer's performance using the scale from 5 to 1 .

Total rating: 5 - Strongly agree, 4 - Agree, 3 - Neither agree nor disagree, 2 - Disagree, 1 Strongly disagree.

The evaluative statements were as follows: 1. The lectures were interesting; 2 . The lectures were well structured; 3 . The lecturer explained the material well; 4. The lecturer highlighted important material well; 5. I could obtain good notes either in the lectures or from online sources; 6 . The lecturer used visual aids effectively ; 7 . The lecturer was clearly audible; 8 . The lecturer did enough worked examples in the lectures and online notes; 9. The course built on my existing knowledge; 10. I found the course useful.

There were 17 respondents, who participated anonymously in the survey. We summarized verbally different results according to the criteria: usefulness and topicality; difficulty/comprehensiveness; rhetoric lecture skills; quality of supporting material; and completeness.

Usefulness and topicality. 9 students found the course useful and they provided an explanation; 5 students were still not sure but found it relatively useful; 3 students found it quite useful and topical.

Difficulty. 3 students replied that the course was not as difficult as expected; 4 students mentioned that it is similarly difficult as any new course; 10 students found it difficult with argumentation.

Comprehensiveness. 11 students found the course comprehensive; 5 as rather comprehensive and 1 student as insufficiently comprehensive. Interestingly, that some students may have confused this word with "difficult".

Rhetoric lecture skills were regarded as very good by 8 students and average by 9 .

As to completeness, apart from study materials and consultations, we focused on the answers to the question concerning the preferable types of texts to be added. This list includes texts with scientific terminology, technology, law, fiction samples, poems and magazine articles, speeches, colloquial and slang texts.

The main challenge of the course is the specific theory, terminology and names of scholars and loosing track of the lecture while listening.

\section{Conclusions}

The results of our study imply that although the course is rather difficult, it is really useful and comprehensive, whereas rhetoric skills should be somewhat improved and certain text types should be added to the syllabus to make it more enjoyable and relevant. We have also revealed that few students have a commissioned professional translating experience, but most of them realize the purport of the course for their future paid practice.

Generally, the students liked the suggested survey and showed more enthusiasm and involvement during the following seminars. After analyzing the texts using the critical reading framework of translational text analysis, they were assigned to select and analyze their own sample and to discuss it with the groupmates and the lecturer.

\section{BIBLIOGRAPHY:}

1. Allen M. The SAGE Encyclopedia of Communication Research Methods. 2017. Vol. 1. URL: https://books.google. com.ua/books?id=4GFCDgAAQBAJ\&pg=PA1754\&lpg=PA $1754 \& d q=$ Mike+Allen+Textual+analysis\&source=bl\&ots $=F$ eJrcdJipH\&sig=ACfU3U3xzKHlj5Uqto9nVJ4eAerqPIRWQ \&hl=ru\&sa=\&ved=2aUKEwi9kOf_6LThAhVxoosKHRHgBu 8Q6AEwAnoECAgQAQ\#v=onpage\&q=Mike\%20Allen\%20 Textual\%20analysis\&f=false. (Last accessed 25.04.2019).

2. Arntz R."Interlingualer Fachsprachenvergleich und Übersetzen" In M. Snell Hornby, F. Pöchhaker, and K. Kaindl (eds), Translation Studies, An Interdiscipline. 1992. Amsterdam: Benjamins. P. 235-246.

3. Bell R.T. Translation and Translating: Theory and Practice. 1991. London/New York : Longman. 298 p.

4. Canzhong Wu. Discourse and TextAnalysis for Translators and Interpreters. 2017. URL: http://handbook.mq.edu.au/2017/ Units/PGUnit/TRAN880. (Last accessed 20.04.2019).

5. Careless B.J. Rediscovering Text Analysis in Translator Training and Further Training - a Macro-Textual and MicroTextual Approach. 2014. P. 396-404. URL: https:// www. academia.edu/11315998/Rediscovering

6. _Text_Analysis_in_Translator_Training_and_Further_ Training_a_Macro-Textual_and_Micro-Textual_Approach. (Last accessed 20.04.2019).

7. Catford J.C. A Linguistic Theory of Translation. Oxford: OUP, 1965. $103 \mathrm{p}$.

8. Halliday M.A.K., Mclntosh A. Patterns of Language: Papers in General, Descriptive and Applied Linguistics. London: Longmans, 1966. $199 \mathrm{p}$.

9. Halliday M.A.K. and Hasan R. Cohesion in English. London, 1976. Longman. 374 p. 
10. House J. "How do we know when a translation is good?", in Steiner, E. \& C. Yallop. 2001. P. 127-160.

11. Kim M. Text Analysis for Translation. 2017. URL: https:// hal.arts.unsw.edu.au/media/HALFile/MODL5106_2017 S1.pdf. (Last accessed 20.04.2019).

12. Коптілов В.В. Першотвір і переклад. Роздуми та спостереження. Київ: Дніпро, 1972. 215 с.

13. Manfredi M. Translating Text and Context. Translation Studies and Systemic Functional Linguistics. Bologna : CeSLiC, 2008. 97 p.

14. Mastnà $E$. The nature of scientific and technical texts from the viewpoint of translation studies. Tomas Bata University in Zlìn, 2010. 73 p.

15. Munday J. Introducing Translation Studies. Routledge, 2001. 222 p.

16. Newmark P. A Textbook of Translation. Prentice Hall, 1988. $292 \mathrm{p}$.

17. Nida E. Toward a Science of Translating. Leiden : E.J. Brill. Netherlands, 1964. 331 p.

18. Nord C. Text analysis in translation: theory, methodology, and didactic application of a model for translation-oriented text analysis. Amsterdam/New York, NY : Rodopi, 1991. 250 p.

19. Nord C. Translating as a Purposeful Activity. Manchester : St. Jerome, 1997. 154 p.

20. RTU. Course "Modern Methods of Text Analysis". 2017. URL: https://www.rtu.Iv/writable/public_files/RTU_via605_ teksta_analizes_modernas_metodes.pdf. (Last accessed 20.04.2019).

21. Schäffner Ch. Text Analysis for Translation. 2011. URL: https://www.google.com/url?sa=t\&rct=j\&q=\&esrc=s\&sour $c e=w e b \& c d=5 \&$ ved $=2$ ahUKEwjajJya9eHhAhXBo4sKHS8 4A3cQFjAEegQIAxAC\&url=http\%3A\%2F\%2Fwww.aston. ac.uk\%2FEasySiteWeb\%2FGatewayLink.aspx\%3Falld\% 3D100805\&usg=AOvVaw0yVSpdRXwFhUvw94IpHMKf. (Last accessed 20.04.2019).

22. Шмігер Т.В. До питання перекладознавчого аналізу: історія та методологія. Харків: Видавничий центр "XAl", 2003. C. 199-201.

23. Trosborg A. Analysing professional genres. John Benjamins Publishing, 2000. 272 p.

24. Wallace $C$. Critical literacy awareness in the EFL classroom. In Fairclough N. (Ed.), Critical language awareness. London and New York : Longman, 1992. P. 59-93.

25. Wallace C. Critical reading in language education. New York : Palgrave Macmillan, 2003. 217 p. DOI: 10.1057/9780230514447. (Last accessed 20.04.2019).

\section{REFERENCES:}

1. Allen M. (2017). The SAGE Encyclopedia of Communication Research Methods. URL: https://books.google.com.ua/ books?id=4GFCDgAAQBAJ\&pg=PA1754\&lpg=PA1754\& $\mathrm{dq}=$ Mike+Allen+Textual+analysis\&source=bl\&ots=FeJrcd JipH\&sig=ACfU3U3xzKHlj5Uqto9nVJ4eAerqPIRWQ\&hl=r u\&sa=X\&ved=2aUKEwi9kOf_6LThAhVxoosKHRHgBu8Q 6AEwAnoECAgQAQ\#v=onepage \&q=Mike $\% 20$ Allen $\% 20$ Textual\%20analysis\&f=false.

2. Arntz R. (1992). "Interlingualer Fachsprachenvergleich und Übersetzen" In M. Snell Hornby, F. Pöchhaker, and K. Kaindl (eds), Translation Studies, An Interdiscipline. Amsterdam: Benjamins, pp. 235-246.

3. Bell R.T. (1991). Translation and Translating: Theory and Practice, London/New York : Longman, 298 p.
4. Canzhong Wu. (2017). Discourse and Text Analysis for Translators and Interpreters. URL: http://handbook. mq.edu.au/2017/Units/PGUnit/TRAN880.

5. Careless B.J. (2014). Rediscovering Text Analysis in Translator Training and Further Training - a MacroTextual and Micro-Textual Approach, pp. 396-404. URL: https:// www.academia.edu/11315998/Rediscovering_ Text_Analysis_in_Translator_Training_and_Further_ Training_a_Macro-Textual_and_Micro-Textual_Approach.

6. Catford J.C. (1965). A Linguistic Theory of Translation, Oxford : OUP, $103 \mathrm{p}$.

7. Halliday M.A.K., McIntosh A. (1966). Patterns of Language: Papers in General, Descriptive and Applied Linguistics, London: Longmans, $199 \mathrm{p}$.

8. Halliday M.A.K. and Hasan R. (1976). Cohesion in English. London : Longman, $374 \mathrm{p}$.

9. House J. (2001). "How do we know when a translation is good?", in Steiner, E. \& C. Yallop, pp. 127-160.

10. Kim M. (2017). Text Analysis for Translation. URL: https://hal. arts.unsw.edu.au/media/HALFile/MODL5106_2017_S1.pdf.

11. Koptilov V.V. (1972). Pershotvir i pereklad. Rosdumy ta sposterezhennia [Original text and translation. Reflections and observations]. Kyiv : Dnipro, $215 \mathrm{p}$.

12. Manfredi M. (2008). Translating Text and Context. Translation Studies and Systemic Functional Linguistics. Bologna : CeSLiC, $97 \mathrm{p}$.

13. Mastnà E. (2010). The nature of scientific and technical texts from the viewpoint of translation studies. Tomas Bata University in Zlin, $73 \mathrm{p}$.

14. Munday, J. (2001). Introducing Translation Studies. Routledge, $222 \mathrm{p}$.

15. Newmark P. (1988). A Texbook of Translation. Prentice Hall, 292 p.

16. Nida E. (1964). Toward a Science of Translating, Leiden : E.J. Brill. Netherlands, 331 p.

17. Nord C. (1991). Text analysis in translation: theory, methodology, and didactic application of a model for translation-oriented text analysis. Amsterdam/New York, NY : Rodopi, $250 \mathrm{p}$.

18. Nord C. (1997). Translating as a Purposeful Activity. Manchester : St. Jerome, $154 \mathrm{p}$.

19. RTU. (2017). Course "Modern Methods of Text Analysis". URL: https://www.rtu.Iv/writable/public_files/RTU_via605_ teksta_analizes_modernas_metodes.pdf.

20. Schäffner Ch. (2011). Text Analysis for Translation. URL: https://www.google.com/url?sa=t\&rct=j\&q=\&esrc=s\&sour $c e=$ web\&cd=5\&ved=2ahUKEwjajJya9eHhAhXBo4sKHS8 4A3cQFjAEegQIAxAC\&url=http\%3A\%2F\%2Fwww.aston. ac.uk\%2FEasySiteWeb\%2FGatewayLink.aspx\%3Falld\% 3D100805\&usg=AOvVaw0yVSpdRXwFhUvw94IpHMKf.

21. Shmiger T.V. (2003). Do pytannia perekladoznavchogo analizu: istoria ta medodologia [To the question of translational analysis: history and methods]. Kharkiv : Vydavnychyi centr "KHAl", pp. 199-201.

22. Trosborg A. (2000). Analysing professional genres. John Benjamins Publishing, $272 \mathrm{p}$.

23. Wallace C. (1992). Critical literacy awareness in the EFL classroom. In Fairclough N. (Ed.), Critical language awareness. London and New York : Longman, pp. 59-93.

24. Wallace C. (2003). Critical reading in language education. New York : Palgrave Macmillan, 217 p. DOI: $10.1057 / 9780230514447$. 